\title{
TEM Training and Practice Through A Specimen Sharing Program: CSI For EM Laboratories
}

\author{
Craig Radi ${ }^{1}$, Sara Miller ${ }^{2}$, Cynthia Goldsmith ${ }^{3}$, Kathy Kurth-Toohey ${ }^{1,4}$
}

1. Wisconsin Veterinary Diagnostic Laboratory, Madison, WI USA

2. Pathology EM, Duke University, Durham, NC USA

3. Infectious Disease Pathology Branch, Centers for Disease Control, Atlanta, GA USA

4. Pathobiological Sciences, School of Veterinary Medicine, University of Wisconsin, Madison, WI USA

Transmission Electron Microscopy (TEM) is a skill that needs to be continually exercised for all microscopists. A trained eye is particularly critical for the identification of unknown agents in diagnostic samples. The limited amount of sample and sample variety provides additional constraints. The "Specimen Sharing Program" was started during the Centers for Disease Control (CDC) and Duke University's "Bioterrorism Training" program. Hosted by Cynthia Goldsmith from the CDC and Dr. Sara Miller from Duke University, the course taught students to prepare and look for viral agents. During the training, it became apparent that many scientists did not receive or have access to a variety of samples containing unknown agents. It was suggested that a program could be put in place to address these concerns. While the Robert Koch Institute (RKI) has a similar program, not all labs were able to participate.

Originally 5 grids of negative stained ${ }^{[1]}$ or sectioned samples ${ }^{[2]}$ were prepared by the authors at Duke University, CDC and the Wisconsin Veterinary Diagnostic Laboratory (WVDL). Grids were shared in a sequential fashion. For example, the first participant would report their answer and mail the grid box to the next laboratory on the list. This process was not satisfactory because the grids did not withstand the extensive handling and shipment. In 2010 the program was changed so that a single inactivated sample was sent to participants to simultaneously prepare their own grids. The results for 2011 and 2012 are presented.

Table 1.

\begin{tabular}{|c|l|l|c|c|c|c|}
\hline Year & Agent & Matrix & $\begin{array}{c}\text { Participating } \\
\text { Labs }\end{array}$ & $\begin{array}{c}\text { Responded } \\
\text { Labs }\end{array}$ & $\begin{array}{c}\text { Confirmed } \\
\text { Virus ID }\end{array}$ & $\begin{array}{c}\text { Missed } \\
\text { Identification }\end{array}$ \\
\hline 2011 & Rhabdovirus & Cell Isolate & 10 & 6 & 6 & 0 \\
\hline 2012 & Herpesvirus & Cell Isolate & 18 & 13 & 12 & 1 Reovirus \\
\hline
\end{tabular}

With 19 labs currently included in this program, all of the participants have matured in their abilities to be challenged in looking for the unknown. This has also enhanced their techniques in sample preparation and generation of quality micrographs. 


\section{References:}

[1] Hayat MA, Miller SE. Negative Staining (McGraw-Hill Pub Co, New York, 1990) 253 p.

[2] Bozzola JJ, Russell LD. Electron Microscopy: Principles and Techniques for Biologists (Jones and Bartlett Pub. Sudbury, MA, 1998) 542 p.
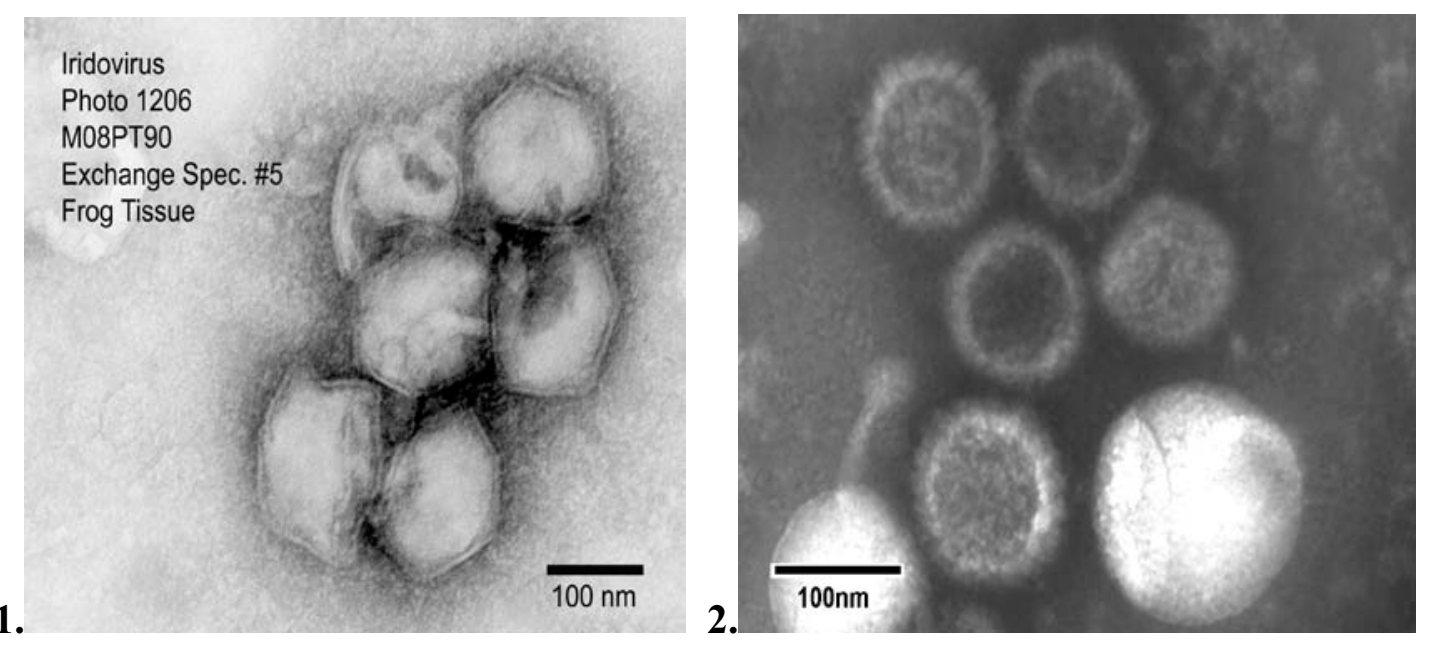

Figure 1. Iridovirus from cell culture isolate, image by Margret Casey Figure 2. Herpesvirus from cell culture isolate, image by Sara Miller
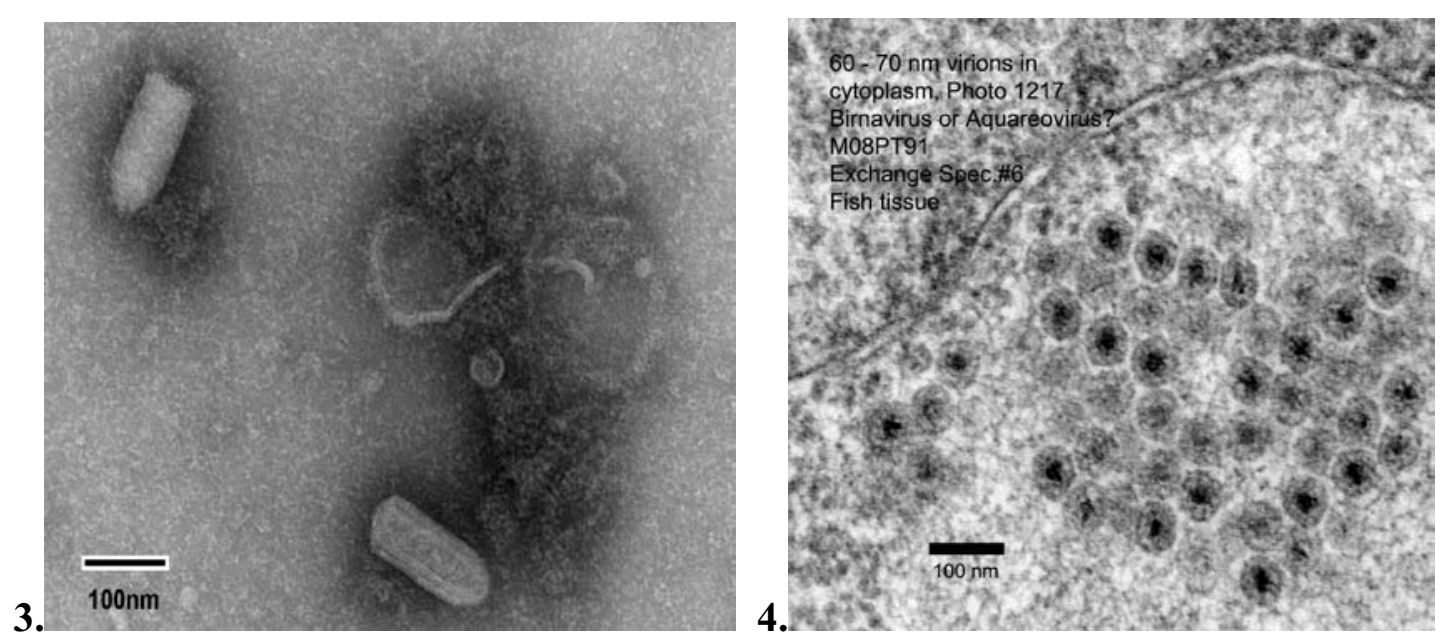

Figure 3. Rhabdovirus from cell culture isolate, image by Maureen Metcalfe Figure 4. Aquareovirus from embedded cell isolate, image by Margret Casey 